\title{
PERUBAHAN LANSKAP EKOLOGI DAN RESILIENSI NAFKAH RUMAHTANGGA PETANI DI SEKITAR HUTAN DI KALIMANTAN TIMUR
}

\author{
(Landscape Ecologcal Changes and Farm Household Livelihoods Resilience Around Forest In \\ East Kalimantan)
}

\author{
Rizka Amalia*, Arya Hadi Dharmawan, Eka Intan Kumala Putri \\ Program Studi Pengelolaan Sumberdaya Alam dan Lingkungan, Institut Pertanian Bogor \\ *)Email : amalrizka@gmail.com \\ Tanggal Diterima: 04 Agustus 2015
}

\begin{abstract}
The expansion of oil palm plantations results in landscape ecologcal changes, deforestation, the loss of crops area and loss of biodiversity. It gives an impact on household livelihood systems in the region. Beside that, Farm household living around the forest that are depending on the land and forests areas. It means that oil palm plantations are vulnerable to socks on livelihood system of farm household. The farm household try to reduce vulnerability by some strategy that use five capital (financial, physical, human resources, natural resources, and social). If the farm household can reduce the vulnerable so farm household build livelihood resilience successfully. The research questions are (1)How the landscape ecological changes affect to the resilience of farm household? (2) How the landscape ecological changes impact on the livelihood structure of farm household?. The study was conducted in Merapun village, Kelay district, Berau Regency, East Kalimantan. The method is uses survey method. The 30 respondents selection through random sampling. The result of the research are the factors of farm household resilience are gender of head household, number of household members, the level of financial capital, household income and the level of trust on the network.
\end{abstract}

Keywords: Oil Palm plantation, Landscape Ecology Changes, Farm Household, Livelihood System, Resilience

\begin{abstract}
ABSTRAK
Ekspansi perkebunan kelapa sawit menghasilkan lanskap perubahan ekologi, deforestasi, hilangnya daerah tanaman dan hilangnya keanekaragaman hayati. Ini memberikan dampak pada sistem mata pencaharian rumah tangga di wilayah tersebut. Selain itu, pertanian keluarga yang hidup di sekitar hutan yang tergantung pada lahan dan hutan. Ini berarti bahwa perkebunan kelapa sawit rentan terhadap kaus kaki pada sistem kehidupan rumah tangga pertanian. Rumahtangga pertanian mencoba untuk mengurangi kerentanan oleh beberapa strategi yang menggunakan lima modal (keuangan, fisik, sumber daya manusia, sumber daya alam, dan sosial). Jika rumah tangga pertanian dapatmengurangi rentan sehingga rumah tangga pertanian membangun ketahanan penghidupan berhasil. Pertanyaan penelitian adalah (1) Bagaimana perubahan ekologi lanskap mempengaruhi ketahanan rumah tangga pertanian? (2) Bagaimana dampak perubahan ekologi lanskap pada struktur kehidupan rumah tangga pertanian ?. Penelitian dilakukan di Desa Merapun, Kecamatan Kelay, Kabupaten Berau, Kalimantan Timur. Metode ini menggunakan metode survei. 30 responden seleksi melalui random sampling. Hasil dari penelitian ini adalah faktor-faktor ketahanan rumah tangga pertanian adalah jenis kelamin kepala rumah tangga, jumlah anggota rumah tangga, tingkat modal, pendapatan rumah tangga dan tingkat kepercayaan pada jaringan.
\end{abstract}

Kata kunci: Ekologi Lansekap Perubahan, Ketahanan, Livelihood System, Perkebunan Kelapa Sawit, Pertanian Rumah Tangga

\section{PENDAHULUAN}

\section{Latar Belakang}

Tanaman kelapa sawit diperkenalkan pertama kali di
Indonesia pada tahun 1911 oleh warga negara Belgia yaitu Adrien Hallet dan K Schadt dengan cara menanamnya secara komersial di Sumatera Utara (Dewanto, 2013). Kemudian pada tahun 1980 terjadi perkembangan dan perluasan perkebunan kelapa sawit di Indonesia, sehingga 
pada tahun 2007 negara Indonesia tercatat sebagai penghasil dan pengekspor minyak kelapa sawit terbesar di dunia (Malau, 2014). Secara umum, perkebunan kelapa sawit membawa dampak positif berupa peningkatan pendapatan rumahtangga, keamanan pekerjaan, peningkatan akses terhadap insfrastruktur/layanan sosial, dan peningkatan nilai lahan (Wakker, 2004; Colchester et al., 2006; Gibbs et al., 2008; Koh dan Wilcove, 2008; Wicke et al., 2008; Wicke et al 2011).Namun, pembukaan perkebunan kelapa sawit dalam skala besar berimbas pada perubahan sistem pertanian desa-desa sekitar (Widiono, 2008). Ujan et al (2013) menyebutkan bahwa perkebunan kelapa sawit juga menyebabkan deforestasi, hilangnya area tanaman pangan dan hilangnya biodiversity, serta hilangnya akses pada lahan dan hilangnya hutan alami tanpa adanya kompensasi yang memadai.

Pembangunan perkebunan kelapa sawit di Indonesia sudah mengarah pada pemanfaatan lahan-lahan di Kalimantan Timur. Kabupaten Berau merupakan salah satu kabupaten yang hutan alamnya masih relatif luas dan utuh, pada tahun 1997 luas tutupan hutannya mencapai 99\% atau sekitar 1,9 juta Ha. Namun pada tahun 2000 luasannya berkurang menjadi 1,8 juta Ha $(86 \%)$, hal ini dikarenakan kegiatan illegal loging, konversi kawasan hutan menjadi perkebunan sawit, pembangunan HTI, dan perluasan kawasan pertambangan batubara serta pemanfaatan kawasan untuk kebutuhan pangan masyarakat (Handoyo; Suka; Ginoga, 2011). Di sisi lain, di Kabupaten Berau juga terdapat masyarakat asli dan lokal yang tinggal di hutan atau di sekitar hutan, sehingga dikhawatirkan dengan adanya ekspansi dan pembangunan perkebunan kelapa sawit yang mengakibatkan perubahan lanskap ekologi sehingga berdampak pada sistem penghidupan masyarakat asli dan lokal (khususnya petani) di Kabupaten Berau. Pada dasarnya rumahtangga petani di sekitar hutan sangat tergantung pada lahan dan hutan, namun dengan adanya perkebunan kelapa sawit diduga memicu risiko guncangan pada sistem penghidupan (livelihood system) rumahtangga petani. Sistem penghidupan rumahtangga petani yang rentan akibat perubahan lanskap ekologi akhirnya memaksa rumahtangga petani melakukan strategi dalam menggunakan lima modal (finansial, fisik, sumberdaya manusia, sumberdaya alam, dan sosial) agar rumahtangga petani dapat menurunkan kerentanan yang dihadapinya dan meningkatkan resiliensinya. Ketika resiliensi nafkah rumahtangga petani berhasil dibangun dan ditingkatkan maka terciptalah penghidupan yang berkelanjutan. Oleh karena itu, penelitian ini perlu dilakukan untuk melihat sejauhmana tingkat resiliensi rumahtangga petani di Kabupaten Berau, Kalimantan Timur akibat adanya perkebunan kelapa sawit.

\section{Perumusan Masalah}

Resiliensi merupakan kemampuan yang berhubungan dengan sistem sosio-ekologi untuk menguraikan bahaya dan penyedia wawasan yang membuat berkurangnya kerentanan (Berkes F., 2007). Resiliensi muncul ketika kapasitas sebuah sistem meningkat dalam mengatasi shock dan krisis. Shock dalam penelitian ini berupa paparan ekspansi perkebunan kelapa sawit yang menyebabkan perubahan lanskap ekologi sehingga menarik untuk dikaji terkait sejauhmana perubahan lanskap ekologi berdampak pada tingkat resiliensi rumahtangga petani?

Perkebunan kelapa sawit menjadikan petani sawah beralih menjadi berkebun kelapa sawit atau menjadi buruh kebun perkebunan kelapa sawit, sehingga mengakibatkan terjadinya perubahan sistem nafkah masyarakat petani. Oleh karena itu, menarik untuk dikaji terkait Sejauhmana perubahan lanskap ekologi akan berdampak pada perubahan struktur livelihood rumahtangga petani?

\section{Tujuan Penelitian}

Tujuan yang diharapkan dari penelitian ini adalah:

1. Mengidentifikasi perubahan lanskap ekologi yang berdampak pada tingkat resiliensi rumahtangga petani.

2. Menganalisis dampak perubahan lanskap ekologi terhadap perubahan struktur livelihood rumahtangga petani.

\section{Ruang Lingkup Penelitian}

Perubahan lanskap ekologi berdampak pada perubahan aspek-aspek rumahtangga petani dan perubahan di masyarakat. Perubahan lanskap ekologi dianggap sebagai stressor yang akan menimbulkan suatu gambaran resiliensi. Resiliensi diidentifikasi melalui indikator Buffer capacity, Self organisation, capacity for learning (Speranza et al., 2014). Indikator-indikator resiliensi merupakan syarat agar terciptanya diversity. Diversity mengacu pada perbedaan dalam karakteristik nafkah (diversifikasi nafkah, diversifikasi hasil panen, biodiversitas, keanekaragaman kelompok sosial) dan proses serta berbagai cara fungsi nafkah.
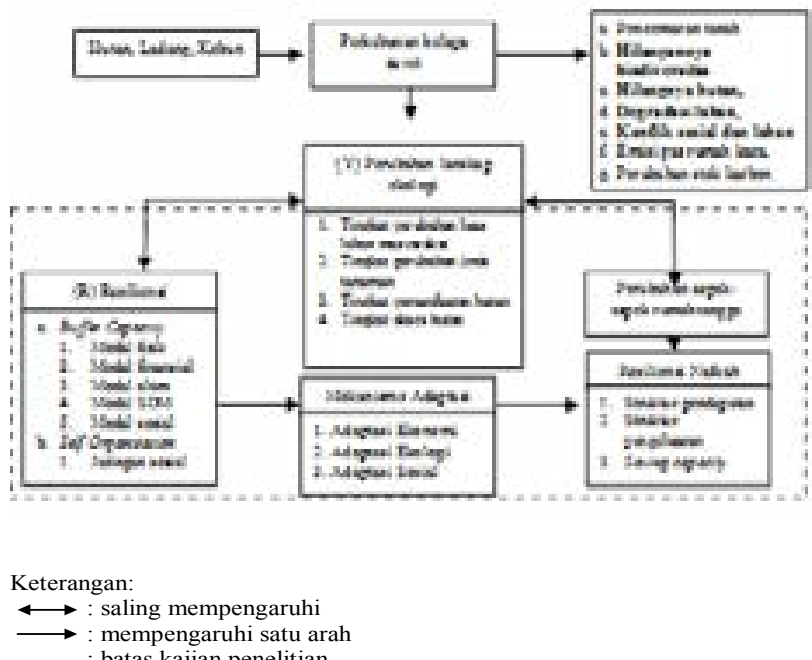

\section{Gambar 1. Kerangka pemikiran penelitian}

Diversitas terhadap pilihan mata pencaharian (livelihood) merupakan hal yang mendasar untuk mengakses sumber penghasilan dalam konteks ruang dan waktu. Sebagian besar masyarakat tradisional mempunyai praktek dan pengetahuan tertentu dalam mengatur sumber penghasilan (resources) dibandingkan dengan ekosistem sederhana yang diciptakan agroindustri monokultur (Berkes dan Folke 1998; Berkes F., 2007).

\section{METODE}

Proses penelitian dilaksanakan dalam bulan November 2014 sampai bulan Agustus 2015. Penelitian ini dilakukan di Desa Merapun, Kecamatan Kelay, Kabupaten Berau, 
Kalimantan Timur. Pemilihan lokasi penelitian karena di wilayah Desa Merapun terdapat konsesi perkebunan kelapa sawit yang merubah lanskap ekologi.

Pemilihan responden dilakukan melalui teknik sampel random sederhana (simple random sampling) sebanyak 30 responden. Alasan menggunakan teknik sampel random sederhana (simple random sampling) adalah populasi sasaran bersifat homogen yaitu rumah tangga petani.

Tabel 1. Tujuan penelitian, jenis data, metode pengumpulan data, dan metode analisis

\begin{tabular}{|c|c|c|c|}
\hline frumlatin & Whath & 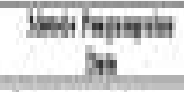 & 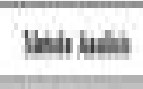 \\
\hline 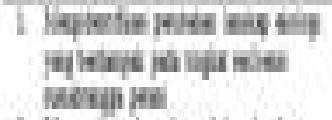 & Phind & 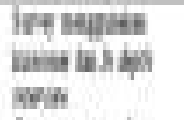 & $\begin{array}{l}\text { Mongt } \\
\text { min }\end{array}$ \\
\hline 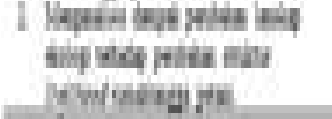 & Hipil & 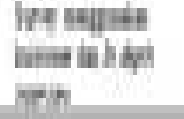 & $\begin{array}{l}\text { Ay } \\
\text { Hall }\end{array}$ \\
\hline
\end{tabular}

Pemilihan informan dilakukan dengan menggunakan metode pengambilan sistem bola salju (snowball). Data yang digunakan dalam penelitian ini meliputi data primer dan data sekunder. Data primer, diperoleh dari survey menggunakan kuisioner dan In depth interview terhadap dua subyek penelitian yaitu responden ${ }^{1}$ dan informan ${ }^{2}$. Data sekunder didapatkan dari Badan Pusat Statistik, jurnal, dan Dinas Kehutanan.

\section{GAMBARAN LOKASI PENELITIAN}

Desa Merapun mempunyai luas wilayah 720,20 Km² (BPS, 2014). Desa Merapun terdiri dari empat Rukun Tetangga (RT) yaitu: RT 1, RT 2, RT 3, dan RT 4. Dari keempat RT tersebut mempunyai karakteristik penduduk yang berbeda-beda. Pada RT 1 mayoritas penduduknya adalah suku Dayak, RT 2 dan 3 mayoritas penduduknya adalah suku campuran, dan RT 4 mayoritas penduduknya adalah pendatang. Jumlah penduduk di Desa Merapun berdasarkan data BPS 2014 yaitu 937 jiwa dan jumlah rumahtangga sebanyak 316 rumahtangga. Fasilitas yang ada di desa Merapun berupa listrik, fasilitas olah raga, sekolah, fasilitas kesehatan, dan jalan. Listrik di Desa Merapun bersumber dari non PLN (genset) yang mengaliri 297 rumahtangga, tenaga surya yang mengaliri 9 rumahtangga, dan petromak yang mengaliri 10 rumahtangga. Selain itu terdapat akses Credit Union (CU), gereja, dan masjid. Infrastruktur berupa jalan sudah ada sejak tahun 2000-an tetapi jalan tersebut jika musim hujan sulit untuk diakses.Pada tahun 2010 jalan tersebut diperbaiki oleh perusahaan perkebunan kelapa sawit sehingga masyarakat dapat mengakses jalan setiap waktu baik pada musim kemarau dan musing penghujan. Mayoritas masyarakat di Desa Merapun masih memanfaatkan air sungai.

1 Responden adalah orang yang memberikan informasi tentang dirinya sendiri.

2 Informan adalah orang yang memberikan informasi tentang orang lain dan lingkungan sekitarnya.

\section{GAMBARAN RESPONDEN}

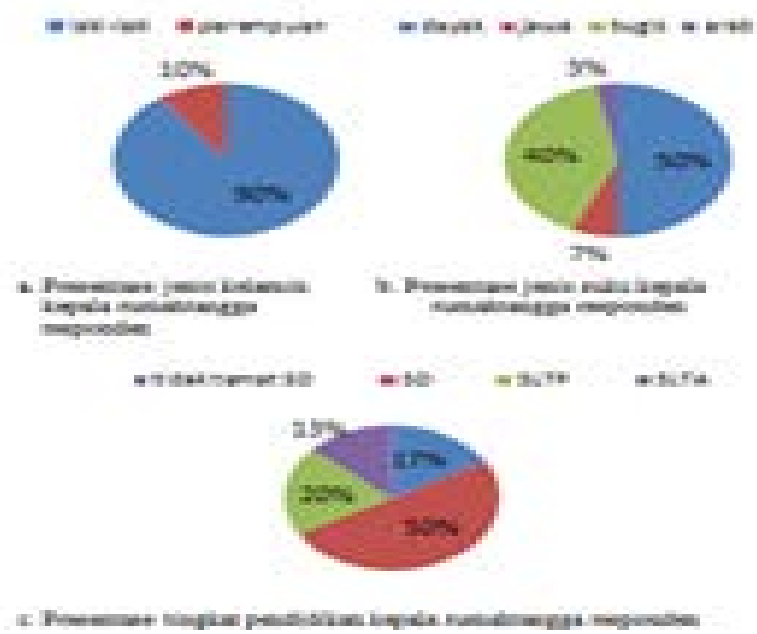

Gambar 2. Karakteristik responden

Dari 30 responden yang telah disurvey menunjukkan bahwa rumahtangga petani yang kepala rumahtangganya adalah laki-laki sebanyak $90 \%$ sementara sisanya dikepalai oleh perempuan. Tingkat pendidikan kepala rumahtangga responden paling dominan (50\%) merupakan tamatan SD.

Kepala rumahtangga responden paling banyak $(50 \%)$ berasal dari suku Dayak. Sementara 50\% lainnya adalah pendatang yang berasal dari suku Jawa, Bugis, dan Arab.

\section{PERUBAHAN LANSKAP EKOLOGI DI DESA MERAPUN}

Wilayah Desa Merapun mengalami perubahan lanskap ekologi bermula dengan adanya HPH yang mulai beroperasi di Desa Merapun pada tahun 1977-2000. HPH ini berupa perusahaan logging yaitu: PT MT, PT KK/ PT GT dan PT AS. Kemudian pada tahun 2004, mulai adanya sosialisasi rencana adanya perkebunan kelapa sawit. Tahun 2005, dimulai pembukaan lahan perkebunan kelapa sawit oleh PT YW. Pada tahun 2014, terdapat enam perkebunan kelapa sawit di Desa Merapun yaitu: PT YW, PT AA, PT GS, PT BS, PT GL, dan PT GA. Dari keenam perkebunan kelapa sawit tersebut terdapat empat perkebunan kelapa sawit yang telah beroperasi dan dua perkebunan kelapa sawit yang masih dalam proses Amdal. Keempat perkebunan kelapa sawit yang telah beroperasi adalah PT YW, PT AA, PT GS dan PT BS. Sementara dua perkebunan kelapa sawit yang masih dalam proses Amdal adalah PT GL dan PT GA. Berdasarkan data BLH Berau (2013), keempat perkebunan kelapa sawit yang telah beroperasi tersebut mempunyai luasan yang berbeda-beda yaitu PT YW seluas $10.000 \mathrm{Ha}$, PT AA seluas 10.000 Ha, PT GS seluas $8.850 \mathrm{Ha}$ dan PT BS seluas $8.400 \mathrm{Ha}$.

Perubahan lanskap ekologi tidak hanya bisa dilihat dalam skala wilayah desa, tetapi juga bisa dilihat dalam skala kecil yaitu perubahan-perubahan lahan yang dimiliki oleh rumahtangga. Perubahan kepemilikan lahan dalam rumahtangga yaitu rata-rata penambahan lahan pada golongan atas yaitu 13,80 Ha, golongan menengah 7,69 $\mathrm{Ha}$ dan golongan bawah 2,84 Ha. Penambahan kepemilikan lahan signifikan terjadi pada rumahtangga petani golongan atas dan menengah. Di sisi lain, terdapat penjualan lahan 
('bajangan'/semak belukar, lahan plasma dan ladang) yang banyak dilakukan oleh rumahtangga petani golongan bawah. Petani menjual lahan plasma karena masyarakat merasa bagi hasil yang didapatkan dari plasma tersebut kurang dapat memenuhi kebutuhan hidup dan menjual ladang atau 'bajangan" karena perubahan gaya hidup seperti membeli motor dan alat elektronik.
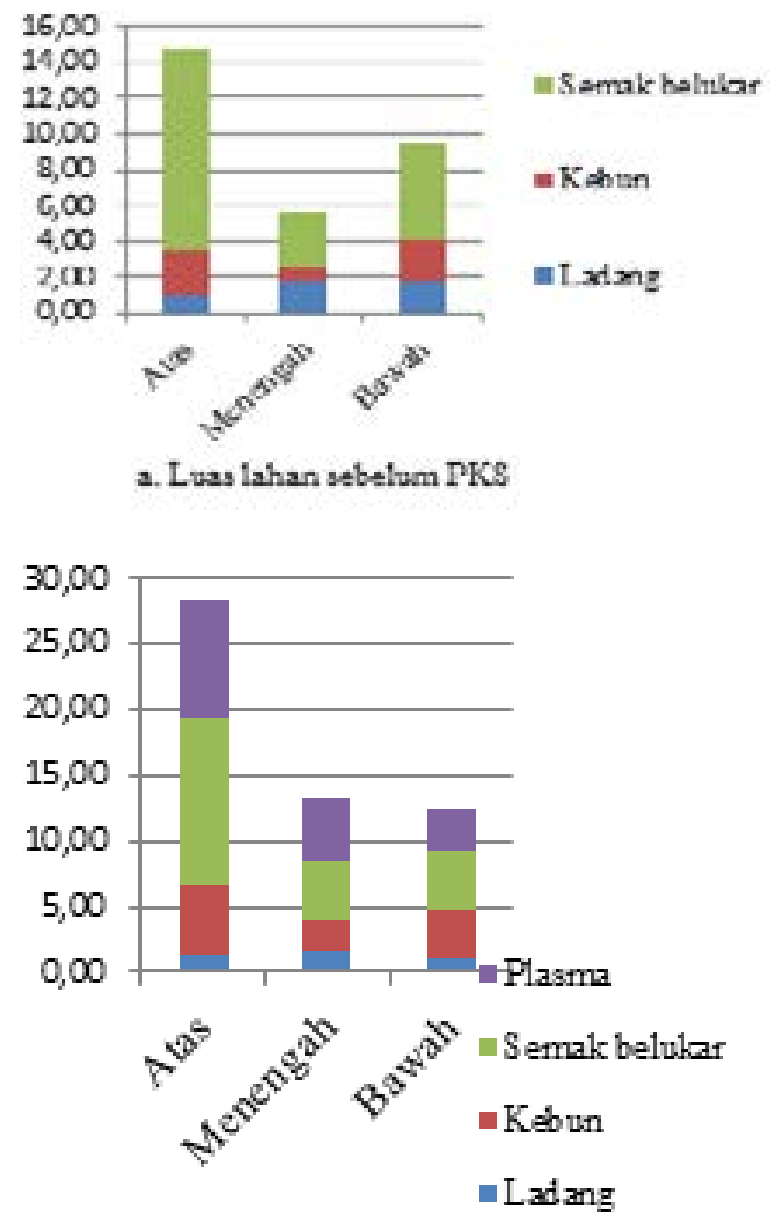

\section{b. Luas lahan sesudah PKS}

Gambar 3. Rata-rata luas lahan (Ha) yang dimiliki rumahtangga petani sebelum dan sesudah operasi perkebunan kepala sawit di Desa Merapun

\section{STRUKTUR LIVELIHOOD RUMAHTANGGA PETANI DI DESA MERAPUN}

Rata-rata rumahtangga petani hanya menanam padi dan ketan di ladang seluas 1-2 Ha. Sementara sisa ladang yang dimiliki tidak diusahakan melainkan hanya dibiarkan saja atau ditanami dengan tanaman buah-buahan, sayur-sayuran dan kelapa sawit. Rumahtangga petani di desa Merapun biasanya hanya bisa bertanam padi dan ketan satu tahun sekali karena ladang yang mereka usahakan merupakan ladang tadah hujan. Ladang $1 \mathrm{Ha}$ hanya dapat memproduksi gabah kering sebesar $4 \mathrm{Kw}-6 \mathrm{Kw}$ sementara ketan yang ditanam hanya dapat diperoleh $\pm 5-15 \mathrm{Kg}$ karena tanaman ketan ditanam hanya sebagai syarat ritual. Padi yang dihasilkan biasanya digunakan untuk memenuhi kebutuhan rumahtangga. Rumahtangga petani mendapatkan cash income dari menjual hasil hutan (madu dan daging binatang buruan), kompensasi dari perusahaan, uang bagi hasil dari plasma perkebunan kelapa sawit, transfer payment, menjual sayur dan palawija dari kebun, dan pendapatan dari non-farm (menjadi buruh PSK, hasil berjualan di toko, sewa truck pada PKS, dan sopir PKS).

Walaupun terdapat bermacam-macam pekerjaan yang dapat menghasilkan cash income tetapi pekerjaan tersebut merupakan pekerjaan non pertanian yang bertumpu pada beroperasinya perkebunan kelapa sawit. Jika perkebunan kelapa sawit ini berakhir maka besar kemungkinan struktur pendapatan tersebut akan runtuh. Keadaan tersebut memperlihatkan bahwa rumahtangga petani mengalami kerentanan yang sangat tinggi akibat adanya perkebunan kelapa sawit.
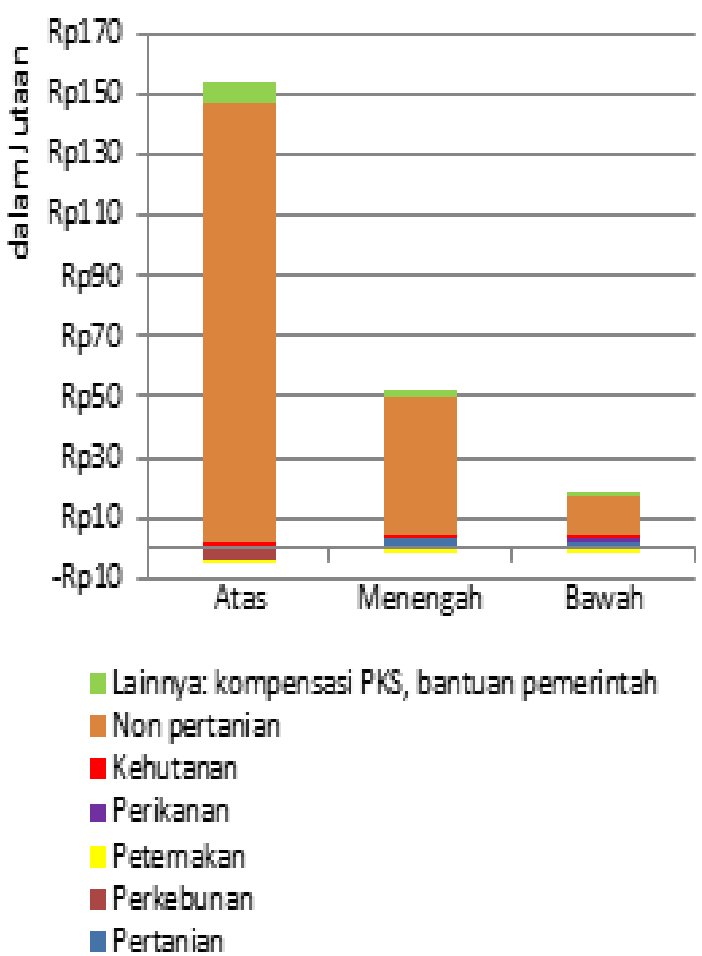

Gambar 4. Rata-rata pendapatan rumahtangga petani di Desa Merapun, 2014.

Pendapatan peternakan pada semua golongan menunjukkan angka minus karena pada tahun 2013-2014 terdapat wabah penyakit yang menyerang hewan ternak unggas (ayam sambung dan ayam kampung) sehingga banyak hewan ternak yang mati sementara selama ayam tersebut hidup terdapat biaya perawatan yang dikeluarkan. Pendapatan dari perkebunan pada golongan atas dan bawah menunjukkan angka minus karena pada golongan atas dan bawah mayoritas berlomba-lomba untuk menanam kelapa sawit dan karet di semak belukar atau ladang yang mereka miliki sehingga banyak modal yang mereka keluarkan sementara tanaman karet dan kelapa sawit mereka belum bisa dinikmati hasilnya.

Pengeluaran paling banyak yang dikeluarkan pada semua golongan rumahtangga petani yaitu pangan (beras, lauk, sayur, dan bumbu dapur). Hal ini karena harga barang yang ada di Merapun relatif mahal. 


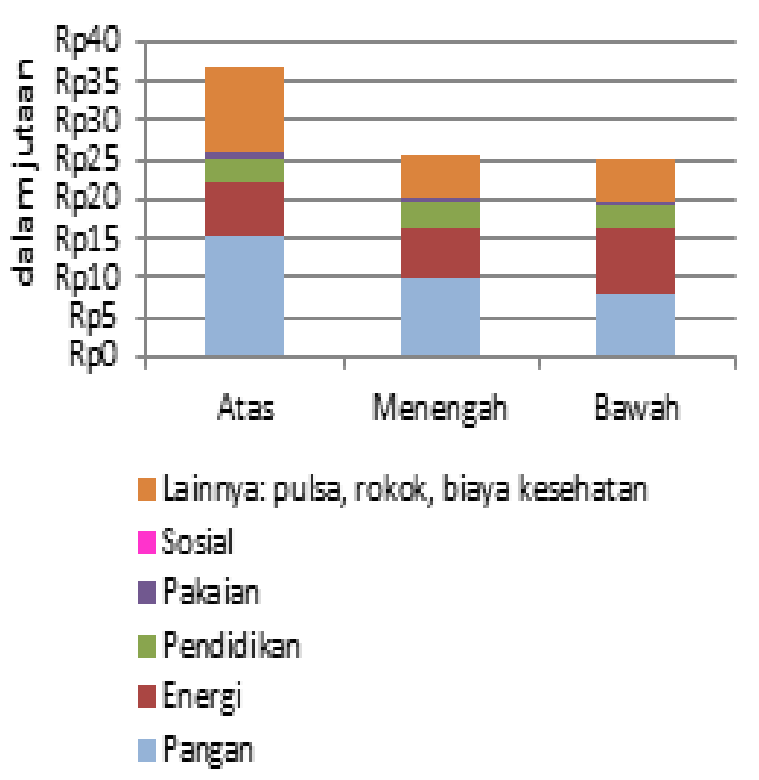

Gambar 5. Rata-rata pengeluaran rumahtangga petani di Desa Merapun, 2014.

\section{MODAL NAFKAH RUMAHTANGGA PETANI DI DESA MERAPUN}

Terdapat lima modal nafkah yang digunakan oleh rumahtangga petani dalam mempertahankan hidupnya. Modal alam meliputi: tingkat ketersediaan sungai dan hutan. Modal Fisik meliputi: tingkat ketersediaan lahan, alat-alat sarana produksi pertanian, alat-alat rumahtangga, dan ternak. Modal sumberdaya manusia meliputi ketersediaan jumlah sumberdaya manusia dan jumlah keterampilan sumberdaya manusia. Modal finasial meliputi: tingkat ketersediaan tabungan. Modal sosial meliputi: jumlah jaringan yang bisa dimanfaatkan.

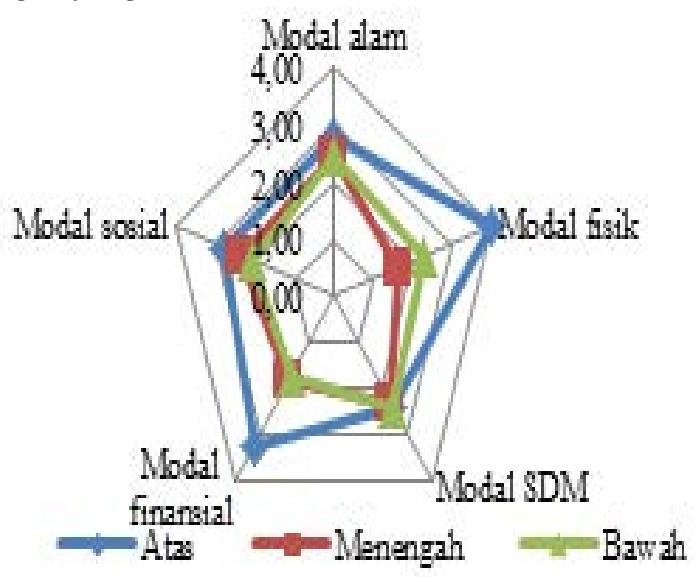

Gambar 6. Lima modal nafkah rumahtangga petani di Merapun, 2014

Ketersediaan modal alam pada semua golongan rumahtangga petani termasuk tinggi karena rumah-rumah penduduk di Desa Merapun berada disepanjang aliran sungai, sehingga rumahtangga petani bisa memanfaatkan sungai untuk mencukupi kebutuhan protein mereka. Sementara hutan memang sudah relatif jauh dari pemukiman walaupun begitu rumahtangga petani masih melakukan aktifitas berburu dengan cara menaiki motor atau mobil. Ketersediaan modal fisik pada rumahtangga petani golongan atas termasuk sangat tinggi. Hal ini terlihat pada rata-rata luasan lahan yang dimiliki oleh rumahtangga golongan atas 28,40 Ha; golongan menengah 13,35 Ha dan golongan bawah 12,34 Ha. Ketersediaan modal sumberdaya manusia pada semua golongan rumahtangga petani termasuk rendah. Hal ini akibat jumlah sumberdaya manusia yang minim yaitu rata-rata hanya 4-5 orang dan jumlah keterampilan yang sedikit. Ketersediaan modal finansial pada rumahtangga petani golongan atas termasuk tinggi, sementara pada golongan menengah dan bawah termasuk rendah. Modal finansial ini tergantung pada ketersediaan tabungan yang dimiliki. Rumahtangga petani golongan atas mempunyai tabungan dengan kisaran $\mathrm{Rp}$ 11.000.000 sampai Rp 66.000.000. Ketersediaan modal sosial pada rumahtangga petani golongan atas termasuk tinggi, sementara pada golongan menengah dan bawah termasuk rendah. Modal sosial ini tergantung pada ketersediaan jumlah jaringan yang bisa dimanfaatkan dalam meningkatkan resiliensi. Jaringan yang dimaksud meliputi: saudara, tetangga, koperasi, layanan bank, lembaga rohani, dan aparat desa.

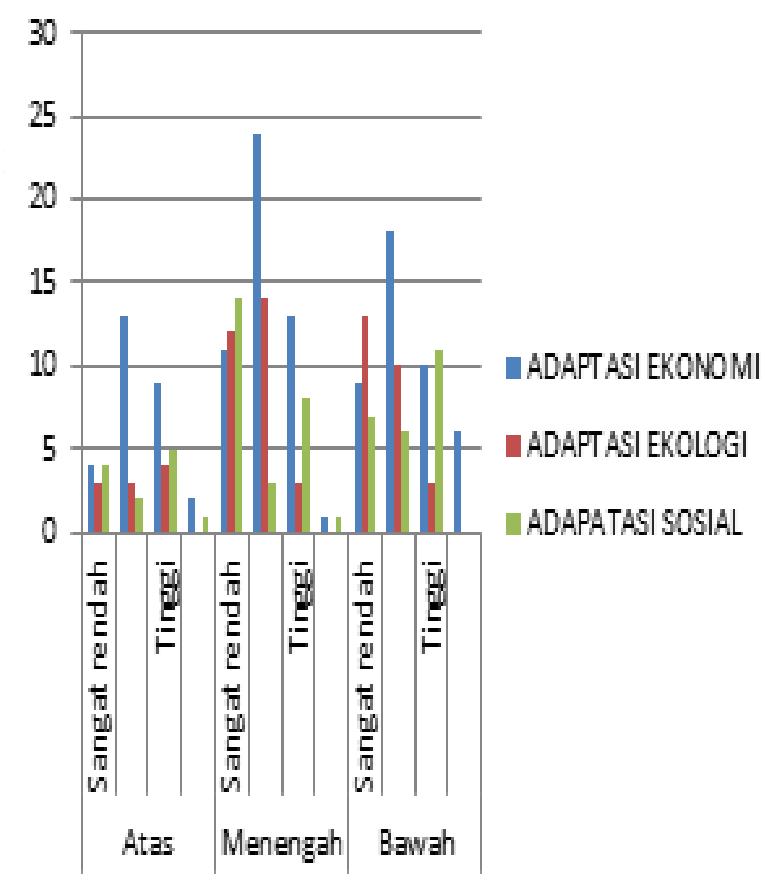

Gambar 7. Strategi adaptasi rumahtangga petani di Desa Merapun, 2014

Bentuk-bentuk strategi adaptasi tersebut dapat diklasifikasikan menjadi tiga, yaitu: (1) adaptasi ekonomi yang memanfaatkan kepemilikan tabungan, menjual benda berharga (lahan, sepeda motor dan perhiasan), memanfaatkan lembaga ekonomi formal (credit union) dan non formal (warung) untuk mendapatkan uang yang dapat menggantikan pendapatan/sumber nafkah yang hilang; (2) adaptasi ekologi yang memanfatkan ketersediaan sumber daya alam (sungai dan hutan) sebagai sumbernafkah alternatif; dan (3) adaptasi sosial yang memanfaatkan ikatan-ikatan sosial di masyarakat, bantuan dari pemerintah, dan dana kompensasi dari PKS. Strategi adaptasi yang paling banyak dilakukan oleh rumahtangga petani golongan atas, menengah dan bawah yaitu strategi 
adaptasi ekonomi. Walaupun strategi ekonomi ini cukup banyak dilakukan oleh rumahtangga petani pada semua golongan tetapi tingkat kebertahanan strategi ini termasuk rendah.

\section{FAKTOR-FAKTOR PENGARUH RESILIENSI NAFKAH RUMAHTANGGA PETANI DI DESA MERAPUN}

Faktor-faktor apa saja yang berpengaruh terhadap resiliensi rumahtangga petani terkait dampak perubahan lanskap ekologi dilihat dengan cara melakukan estimasi variable yang berpengaruhnya. Hasil estimasi model resiliensi rumahtangga petani dalam terkait perubahan lanskap ekologi disajikan pada table 2 .

Tabel 2. Faktor-Faktor yang Mempengaruhi Resiliensi Rumahtangga terkait perubahan lanskap ekologi di Merapun, 2014

\begin{tabular}{|c|c|c|c|c|c|}
\hline \multirow[b]{3}{*}{ Model } & \multicolumn{2}{|c|}{ Coefficients $^{\mathrm{a}}$} & \multirow[b]{2}{*}{$\begin{array}{l}\text { Standardized } \\
\text { Coefficients }\end{array}$} & \multirow[b]{3}{*}{$\mathrm{T}$} & \multirow[b]{3}{*}{ Sig. } \\
\hline & \multicolumn{2}{|c|}{ Unstandardized Coefficients } & & & \\
\hline & B & Std. Error & Beta & & \\
\hline 1 (Constant) & .220 & .812 & & .270 & .790 \\
\hline UmurkepalaRT & -.005 & .008 & -.144 & -.649 & .525 \\
\hline JeniskelaminRT & .670 & .287 & .455 & 2.334 & $.032^{*}$ \\
\hline tingkatpendidikanRT & -.059 & .107 & -.120 & -.549 & .590 \\
\hline JumlahanggotaRT & .131 & .078 & .538 & 1.678 & $.112^{* *}$ \\
\hline tingkatmodalalam & -.156 & .118 & -312 & -1.316 & .206 \\
\hline tingkatmodalfisik & .089 & .099 & .249 & .905 & .378 \\
\hline tingkatmodalfinansial & .319 & .125 & .823 & 2.556 & $.020^{*}$ \\
\hline tingkatmodalSDM & .023 & .177 & .036 & .129 & .899 \\
\hline tingkatmodalsosial & -.217 & .235 & -.292 & -.925 & .368 \\
\hline pendapatanrumahtangga & $-6.202 \mathrm{E}-9$ & .000 & -.726 & -2.172 & $.044^{*}$ \\
\hline $\begin{array}{l}\text { tingkatkepercayaanpadaja } \\
\text { ringan }\end{array}$ & .414 & .208 & .579 & 1.995 & $.062 * *$ \\
\hline jumlahlahanyangdimiliki & -.003 & .012 & -.090 & -.282 & .78 \\
\hline
\end{tabular}

\begin{tabular}{|l|c|r|r|r|}
\hline Model & \multicolumn{1}{|c|}{ M } & R Square & $\begin{array}{c}\text { Adjusted R } \\
\text { Square }\end{array}$ & $\begin{array}{c}\text { Std. Error of } \\
\text { the Estimate }\end{array}$ \\
\hline 1 & $.689^{2}$ & .474 & .104 & .426 \\
\hline
\end{tabular}

\begin{tabular}{|c|c|c|c|c|c|}
\hline \multicolumn{6}{|c|}{ ANOVA $^{\mathrm{b}}$} \\
\hline Model & $\begin{array}{l}\text { Sum of } \\
\text { Squares }\end{array}$ & Df & Mean Square & F & Sig. \\
\hline Regression & 2.784 & 12 & .232 & 1.279 & $.313^{2}$ \\
\hline Residual & 3.083 & 17 & .181 & & \\
\hline Total & 5.867 & 29 & & & \\
\hline
\end{tabular}

\footnotetext{
* : signifikan pada taraf nyata $(\alpha=0,05)$

** : signifikan pada taraf nyata $(\alpha=0,2)$

Sumber: Data primer 2014 yang sudah diolah
}

Fungsi resiliensi rumahtangga memiliki R-sq sebesar 47\%. Artinya, bahwa keragaman model resiliensi dapat dijelaskan oleh keragaman variabel bebas di dalam model sebesar $47 \%$, sedangkan sisanya $53 \%$ dijelaskan oleh variabelvariabel lain yang tidak terdapat dalam model. Faktorfaktor yang mempengaruhi resiliensi nafkah rumahtangga petani yaitu jenis kelamin kepala rumahtangga, jumlah anggota rumahtangga, tingkat modal finansial, pendapatan rumahtangga dan tingkat kepercayaan pada jaringan.

\section{KESIMPULAN}

Wilayah Desa Merapun mengalami perubahan lanskap ekologi bermula dari adanya HPH kemudian disusul dengan adanya perkebunan kelapa sawit. Perubahan lanskap ekologi tidak hanya dilihat dalam skala wilayah desa, tetapi juga bisa dilihat dalam skala kecil yaitu perubahan-perubahan lahan yang dimiliki oleh rumahtangga. Penambahan kepemilikan lahan dominan terjadi pada rumahtangga petani golongan atas dan menengah. Sementara, penjualan lahan banyak dilakukan oleh rumahtangga petani golongan bawah. Ratarata rumahtangga petani hanya menanam padi dan ketan di ladang seluas 1-2 Ha sebagai usaha subsisten. Rata-rata pendapatan rumahtangga petani di Desa merapun yang didominasi oleh pendapatan non pertanian. Kepemilikan modal sosial dan alam pada golongan atas, menengah dan bawah tergolong tinggi. Strategi adaptasi yang paling banyak dilakukan oleh rumahtangga petani golongan atas, menengah dan bawah yaitu strategi adaptasi ekonomi. Faktor yang mempengaruhi resiliensi nafkah rumahtangga petani yaitu jenis kelamin kepala rumahtangga, jumlah anggota rumahtangga, tingkat modal finansial, pendapatan rumahtangga dan tingkat kepercayaan pada jaringan.

\section{DAFTAR PUSTAKA}

Berkes F., 2007. Understanding uncertainty and reducing vulnerability: lessons from resilience thinking. Springer Science+Business Media. Nat Hazards 9 2007 41: 283-295 DOI 10.1007/st 1069-006-90367

Badan Lingkungan Hidup [BLH] Berau. 2013. Data AMDAL yang disetujui. [internet]. Diunduh pada tanggal 7 Maret 2015. \{www. BLH berau.go.id/ data_amdal-yang_disetujui_2013/\}

Badan Pusat Statistik [BPS]. 2014. Hasil publikasi kelapa sawit. [internet]. Diunduh pada tanggal 15 Desember 2014. \{http://www.bps.go.id/hasil_publikasi/dir_ kelapa_sawit_2012/files/search/searchtext.xml\}

Badan Pusat Statistik [BPS]. 2014. Kabupaten Berau dalam angka 2014. [internet]. Diunduh pada tanggal 7 Maret 2015. \{http://www.bps.go.id/kabupaten berau_dalam_angka_2014/files/search/searchtext. $\mathrm{xml}\}$

Badan Pusat Statistik [BPS]. 2014. Kecamatan Kelay dalam angka 2014. [internet]. Diunduh pada tanggal 7 Maret 2015. \{http://www.bps.go.id/kecamatan kelay_dalam_angka_2014/files/search/searchtext. $\mathrm{xml}\}$

Dewanto F.A., 2013. Melihat jejak perkebunan kelapa sawit di Indonesia. [internet]. Diunduh pada tanggal 15 Desember 2014. \{http://beritadaerah. co.id/2013/10/31/melihat-jejak-perkebunan-kelapasawit-di-indonesia/\}

Handoyo, Suka A.P., Ginoga K.L.,2011. Identifikasi tenurial sebagai pra-kondisi untuk implementasu REDD+. Jurnal penelitian sosial dan ekonomi 8 Desember (2011) 306-320

Malau F.P., 2014. Ketika perkebunan kelapa sawit tertuduh merusak lingkungan. [internet]. Diunduh pada tanggal 15 Desember 2014 \{http://www.bumn. go.id/ptpn6/berita/2 144/Ketika.Perkebunan. KelapaSawittertuduh.Merusak.Lingkungan\}

Speranza, C.I., Wiesmann U., Rist S., 2014. An indivator framework for assessing livelihood resilience in the context of social-ecological dynamics. Global Environmental Change 28 (2014) 109-119\} 
Unjan R., Nissapa A., Phitthayaphinant P., 2013. An Identification of Impacts of Area Expansion Policy of Oil Palm in Southern Thailand: A Case Study in Phatthalung and Nakhon Si Thammarat Provinces. Procedia - Social and Behavioral Sciences 91 ( 2013 ) $489-496$

Wicke B., Sikkema R., Dornburg V., Faaij A., 2011. Exploring land use changes and the role of palm oil production in Indonesia and Malaysia. Land Use Policy 28 (2011) 193-206

Widiono, S., 2008. Pembangunan perkebunan kelapa sawit serta dampaknya terhadap pelapisan sosial dan strategi nafkah: kasus dua desa Sawah Etnis Serawai dan Jawa di Kabupaten Seluma, Profinsi Bengkulu. [tesis]. Bogor: Sekolah pascasarjana Institut pertanian Bogor 
